\title{
ldentifying activating mutations in the EGFR gene: prognostic and therapeutic implications in non-small cell lung cancer*
}

\author{
ldentificação de mutações ativadoras no gene EGFR: implicações no \\ prognóstico e no tratamento do carcinoma pulmonar de células não pequenas
Gabriel Lima Lopes', Edoardo Filippo de Queiroz Vattimo², Gilberto de Castro Junior ${ }^{2,3}$

\begin{abstract}
Lung cancer is the leading cause of cancer-related deaths worldwide. Promising new therapies have recently emerged from the development of molecular targeted drugs; particularly promising are those blocking the signal transduction machinery of cancer cells. One of the most widely studied cell signaling pathways is that of EGFR, which leads to uncontrolled cell proliferation, increased cell angiogenesis, and greater cell invasiveness. Activating mutations in the EGFR gene (deletions in exon 19 and mutation L858R in exon 21), first described in 2004, have been detected in approximately $10 \%$ of all non-squamous non-small cell lung cancer (NSCLC) patients in Western countries and are the most important predictors of a response to EGFR tyrosine-kinase inhibitors (EGFR-TKIs). Studies of the EGFR-TKls gefitinib, erlotinib, and afatinib, in comparison with platinumbased regimens, as first-line treatments in chemotherapy-naïve patients have shown that the EGFR-TKls produce gains in progression-free survival and overall response rates, although only in patients whose tumors harbor activating mutations in the EGFR gene. Clinical trials have also shown EGFR-TKls to be effective as secondand third-line therapies in advanced NSCLC. Here, we review the main aspects of EGFR pathway activation in NSCLC, underscore the importance of correctly identifying activating mutations in the EGFR gene, and discuss the main outcomes of EGFR-TKI treatment in NSCLC.
\end{abstract}

Keywords: Molecular targeted therapy; Receptor, epidermal growth factor; Lung neoplasms/drug therapy;

Mutation; Oncogenes.

\section{Introduction}

Because of its high incidence and high mortality, lung cancer represents a major challenge for modern oncology. In Brazil, there were an estimated 27,330 new cases of lung cancer in 2014. ${ }^{(1)}$ Recent global estimates indicate that there are 1.6 million new cases and 1.4 million lung cancer deaths each year, the majority of cases (55\%) occurring in developing countries. ${ }^{(2,3)}$ Historically, non-small cell lung cancer (NSCLC) presents response rates to classical cytotoxic chemotherapy in the range of 20-30\%, the median overall survival typically being 8-10 months. ${ }^{(4)}$ The recent development of novel therapeutic agents directed at targets that are aberrantly activated in cancer cells, particularly those within the signal transduction machinery, has opened new vistas for the treatment of NSCLC.

Among the components of the neoplastic phenotype, potential therapeutic targets include cell surface receptors, which have been the focus of intensive research because they play an important role in the processes of cell proliferation, survival, and invasiveness. Remarkable progress has been achieved with the advent of EGFR tyrosinekinase inhibitors (EGFR-TKls), which are able to inhibit EGFR signal transduction. Among patients with NSCLC, those with tumors that harbor activating mutations in the EGFR gene can benefit from treatment with an EGFR-TK1. It is therefore important that such patients are

*Study carried out at the Instituto do Câncer do Estado de São Paulo and at the Hospital das Clínicas, Faculdade de Medicina, Universidade de São Paulo, São Paulo (SP) Brasil.

1. Hospital Sírio-Libanês, São Paulo (SP) Brasil.

2. Faculdade de Medicina, Universidade de São Paulo, São Paulo (SP) Brasil.

3. Serviço de Oncologia Clínica, Instituto do Câncer do Estado de São Paulo, São Paulo (SP) Brasil.

Correspondence to: Gilberto de Castro Junior. Serviço de Oncologia Clínica, Instituto do Câncer do Estado de São Paulo, Hospital das Clínicas, Faculdade de Medicina, Universidade de São Paulo, Avenida Dr. Arnaldo, 251, $5^{\circ}$ andar, CEP 01246-000, São Paulo, SP, Brasil.

Tel.: 5511 3893-2686. Fax: 5511 3083-1746. E-mail: gilberto.castro@usp.br

Financial support: None.

Submitted: 13 January 2015. Accepted, after review: 14 May 2015. 
correctly identified in clinical practice. Ten years after activating mutations in the EGFR gene were recognized as being the most important predictors of a response to EGFR-TKls, ${ }^{(5,6)}$ the present article will review the literature related to the EGFR signaling pathway and to activating mutations in the EGFR gene, as well as discussing the implications of this knowledge for daily practice.

\section{EGFR and its signaling pathways}

Cell surface receptors, which are proteins located in the plasma membrane, play a key role in cellular and tissue physiology. These receptors are activated by stimuli that originate from the external environment (ligands), generating intracellular signals that are transduced by multiple molecular cascades, in which successive phosphorylation of substrates activates the transcription of genes involved in cell proliferation, differentiation, invasion, angiogenesis, metastasis, and resistance to apoptosis. The ErbB receptor family, also known as the c-erb-B or human EGFR (HER) family, has four members: EGFR (or c-erb-B1 or HER-1), c-erb-B2 (or HER-2/neu), c-erb-B3 (or HER-3), and c-erb-B4 (or HER-4). The structure of EGFR, first described in the 1960s by Cohen, ${ }^{(7)}$ comprises three domains: the extracellular domain (the N-terminal portion); the transmembrane domain; and the intracellular C-terminal domain (a hydrophobic portion with tyrosine-kinase activity). The extracellular domain confers binding specificity, ligands including EGF itself as well as TGF- $\alpha$, amphiregulin, and betacellulin. ${ }^{(8)}$ The intracellular domain is capable of phosphorylating tyrosine residues within the receptor itself (autophosphorylation) and within proteins involved in signal transduction.

The interaction between EGFR ligands and the extracellular domain of the receptor leads to its dimerization, ${ }^{(9)}$ which promotes the activation of the tyrosine-kinase domain located in the intracellular domain of the receptor. Once active, the latter domain promotes autophosphorylation of specific sites within the C-terminal domain of EGFR. ${ }^{(10)}$ Signal transduction is then continued by the interaction of those autophosphorylation sites with proteins that contain a Src homology 2 domain or a phosphotyrosine binding domain. ${ }^{(11)}$ Various phosphorylation sites have been identified in the C-terminal domain of EGFR, each leading to interaction with different types of molecules and activation of various cellular pathways. Foremost among these is the Ras/Raf/mitogen-activated protein kinase (MAPK) pathway, in which the adaptor protein Grb2 binds to phosphorylated tyrosine residues of EGFR, thus activating the Son of sevenless protein. ${ }^{(12)}$ This protein in turn activates the G-protein Ras, which initiates a cascade of phosphorylation of MAPKs, which are specific serine/threonine kinases. Those proteins in turn activate gene transcription related to various regulatory functions, including cell division, motility, and adhesion. ${ }^{(13)}$ Another important pathway related to EGFR and activated in NSCLC is that mediated by $\mathrm{Pl} 3 \mathrm{~K}$, which is responsible for activation of serine/threonine kinase Akt. Together with the mammalian target of rapamycin, Akt participates in the regulation of many cellular processes, such as glycolytic metabolism, apoptosis, proliferation, and angiogenesis. ${ }^{(14)}$

The role that EGFR plays in carcinogenesis became clearer after the identification (in the 1980s) of the v-erb-B oncogene protein, which is related to avian erythroblastosis virus and structurally similar to EGFR. ${ }^{(15)}$ The mechanisms leading to increases in proliferative activity, invasiveness, and angiogenesis, as well as in resistance to chemotherapy and radiotherapy, include paracrine and autocrine stimulation in the tumor microenvironment through increased production of ligands (mainly EGF and TGF- $\alpha$ ), overexpression of EGFR molecules on the membrane of tumor cells, and activating mutations in the EGFR gene, all of which affect their signal transduction pathways. ${ }^{(16)}$

\section{The development of EGFR-TKls for the treatment of NSCLC}

As studies have clarified the role of EGFR in carcinogenesis, interest in inhibiting the tyrosinekinase activity of EGFR has grown. The first EGFR-TKls were synthesized in the 1990s. The 4-anilinoquinazoline derivative gefitinib (ZD1839; AstraZeneca, London, England) was the first EGFR-TK1 to obtain approval from the US Food and Drug Administration (FDA). In 2003, the FDA approved gefitinib for the treatment of advanced NSCLC after failure of conventional therapy. ${ }^{(17)}$ In 2004, another EGFR-TKl, erlotinib (OSI-774; Genentech, Roche Group, South San Francisco, CA, USA) was approved by the FDA for the treatment of NSCLC after failure of cytotoxic chemotherapy. ${ }^{(18)}$ More recently (in 2014), the irreversible ErbB family blocker afatinib (BIBW- 
2992; Boehringer Ingelheim Pharmaceuticals, Ingelheim am Rhein, Germany) was also approved by the FDA for clinical use in chemotherapynaïve patients whose tumors harbor activating mutations in the EGFR gene. ${ }^{(19)}$

\section{Mechanisms of action}

Inhibition of the tyrosine-kinase activity of EGFR, whether reversibly (by gefitinib and erlotinib) or irreversibly (by afatinib), is due to the competition of these drugs with ATP molecules for binding sites in the C-terminal domain (catalytic sites) of the receptor. Blocking the phosphorylation of those sites prevents signal transduction through downstream components of the pathway by blocking activation of, for example, the MAPK and Pl3K/Akt/mammalian target of rapamycin pathways. ${ }^{(20)}$ As a result, these TKls interfere with important aspects of tumor viability, leading to reduced proliferation, survival, and angiogenesis of cancer cells, as well as promoting their apoptosis by increasing their sensitivity to the toxic effects of chemotherapy and radiotherapy. ${ }^{(21)}$

\section{Results from clinical trials in unselected populations}

Before activating mutations in the EGFR gene had been identified as predictors of a response to EGFR-TKls, ${ }^{(5,6)}$ clinical trials were conducted in unselected populations of patients with advanced NSCLC. Two sequential phase 11 trials evaluating the activity of gefitinib in patients with NSCLC previously treated with cytotoxic chemotherapy showed response rates of up to $19 \%$, median overall survival of approximately 8 months, and one-year survival of up to $35 \% .^{(22,23)}$ However, in two sequential phase 111 trials, the combination of gefitinib and platinum-based conventional chemotherapy, as a first-line treatment, was not found to be superior to placebo plus chemotherapy, with no significant differences being found in terms of response rates or overall survival. ${ }^{(24,25)}$ Likewise, two separate phase 111 trials showed that the combination of erlotinib and cytotoxic chemotherapy did not improve response rates or overall survival in comparison with chemotherapy alone. $^{(26,27)}$

An international, randomized, placebocontrolled trial of treatment with erlotinib after the failure of standard chemotherapy for NSCLC, involving 731 patients with advanced NSCLC that had previously been treated with first- or second-line platinum-based chemotherapy, was conducted between August of 2001 and January of 2003. ${ }^{(28)}$ Among those patients (some of whom were treated in Brazil), erlotinib led to improvements in overall survival (median of 6.7 months in the erlotinib-treated group vs. 4.7 months in the placebo group; hazard ratio $[\mathrm{HR}]=0.70 ; \mathrm{p}<$ 0.001 ) and in one-year survival (31\% vs. $22 \%$ ). The response rate was also higher in the erlotinib group ( $8.9 \%$ vs. $<1 \% ; p<0.001)$. It is of note that the authors of that study identified specific subgroups of patients in which treatment with erlotinib provided greater benefit: those with adenocarcinoma; those who were female; those of Asian descent; and those with no smoking history. Those results corroborated the emerging body of literature regarding which patients are most likely to derive clinical benefit from the use of EGFR-TKls. ${ }^{(22,23,29)}$ A study using a similar design compared gefitinib with placebo in 1,692 patients with advanced refractory NSCLC and demonstrated that the median progression-free survival was significantly longer in the gefitinibtreated group (2.2 months vs. 1.8 months; HR = $0.61 ; p<0.001) .{ }^{(30)}$ However, that was considered a negative study, because there was no significant difference in the primary endpoint, i.e., overall survival. Another phase 111 trial involving an unselected population compared gefitinib with docetaxel in 1,443 patients with advanced NSCLC after failure of platinum-based, firstline chemotherapy. ${ }^{(31)}$ In that study, gefitinib was not found to be inferior to docetaxel in terms of median overall survival (7.6 months vs. 8.0 months; $H R=1.02)$. It is noteworthy that pemetrexed has also been shown to be comparable to docetaxel in this setting. ${ }^{(32)}$

\section{Activating mutations in the EGFR gene and response to EGFR-TKls}

Independent work by two groups led to the seminal discovery that tumors responding to an EGFR-TK1 typically harbor activating mutations, most often located in exon 19 (del19) or exon 21 (L858R) of the EGFR gene. ${ }^{(5,6)}$ These mutations cause structural alterations in the ATP-binding site of the intracellular domain of EGFR, thus increasing the affinity for TKls and leading to clinical responses. Although the first four exons encoding the tyrosine-kinase domain of EGFR 
(exons 18 through 21) have been identified as major sites for activating mutations, small deletions in exon 19 and point mutations in exon 21 account for over 90\% of such mutations. ${ }^{(33)}$ Other, less common mutations have also been identified, including specific nucleotide substitutions at codon 719 of exon 18 (G719S) and insertions at codon 20. ${ }^{(34)}$ Exon 19 deletions and the L858R mutation lead to a constitutively activated receptor state, as well as to a greater response upon ligand stimulation. ${ }^{(35)}$ It has also been shown that these mutations lead to constitutive activation of Akt, which translates to greater survival. ${ }^{(36)}$ Activating mutations in the EGFR gene have been observed in $8-15 \%$ of all NSCLC patients worldwide and in 25-30\% of those in Brazil. ${ }^{(37,38)}$

Some patients who show an initial response to first-generation TKls (erlotinib and gefitinib) experience disease progression, and many of those patients display secondary EGFR mutations or MET amplification. Approximately 50\% of such patients have tumors that harbor the T790M mutation, and another $\approx 20 \%$ have tumors with MET amplifications. ${ }^{(39,40)}$ Specific inhibitors of the T790M mutation (AZD9291 and C01696) are under study, as are potential MET inhibitors (onartuzumab and tivantinib). ${ }^{(40)}$ However, none of those have proven to be clinically effective in this scenario. ${ }^{(41)}$ The second-generation EGFR-TK1 afatinib is an irreversible ErbB family blocker that is effective in patients with the more common mutations and seems to be effective even in patients with the less common mutations, including the T790M mutation in exon 20, which is one of the main mechanisms of resistance to firstgeneration EGFR-TKls. ${ }^{(39)}$

\section{Clinical studies in mutation-rich populations}

The findings described above paved the way for a novel generation of clinical trials that aimed to evaluate the performance of EGFR-TKls in populations selected for activating mutations in the EGFR gene. The results from the main studies are summarized in Table 1.

A phase 111 clinical trial of the EGFR-TK1 gefitinib, in comparison with the carboplatinpaclitaxel combination, in patients with advanced lung adenocarcinoma (designated the IPASS study, conducted in Asia) included patients with clinical features known to be associated with a higher rate of response to TKls. ${ }^{(42)}$ The patients, all of whom were nonsmokers or former light smokers, were randomized to first-line treatment with gefitinib or with carboplatin plus paclitaxel. The one-year progression-free survival rate was higher in the gefitinib arm than in the carboplatinpaclitaxel arm (24.9\% vs. 6.7\%). In addition to achieving its primary objective of demonstrating the non-inferiority of gefitinib as a first-line treatment for advanced lung adenocarcinoma in clinically selected patients, the IPASS study also demonstrated the superiority of gefitinib in this setting. In addition, retrospective evaluation of the EGFR mutation status in tumor samples demonstrated that even within the clinically selected IPASS population, a response to gefitinib correlated strongly with the presence of activating mutations in the EGFR gene, corroborating their predictive role. Among the mutation-positive patients, the objective response rate to gefitinib was $71.2 \%$, compared with $47.3 \%$ for the carboplatin-paclitaxel combination, whereas the inverse was observed among the patients with no mutations, who showed objective response rates to gefitinib and to the carboplatin-paclitaxel combination of $1.1 \%$ and $23.5 \%$, respectively. The IPASS data also demonstrate that tumors harboring activating mutations in the EGFR gene are more chemosensitive, showing higher response rates than do wild-type tumors. Maemondo et al. ${ }^{(43)}$ also evaluated gefitinib, in comparison with the carboplatin-paclitaxel combination, as firstline therapy in patients whose tumors harbored activating mutations in the EGFR gene. The authors found that the median progression-free survival among the patients treated with gefitinib was 10.8 months, double the 5.4 months observed among the patients treated with the carboplatinpaclitaxel combination. In addition, the one- and two-year progression-free survival rates were $42.1 \%$ and $3.2 \%$, respectively, in the gefitinib group, compared with $8.4 \%$ and $0 \%$, respectively, in the carboplatin-paclitaxel group. Finally, the objective response rate was significantly higher in the gefitinib group than in the carboplatinpaclitaxel group (73.7\% vs. $30.7 \%){ }^{(43)}$ In a similar study, Mitsudomi et al. ${ }^{(44)}$ compared gefitinib with cisplatin plus docetaxel as the first-line treatment of patients with mutations. As in the other studies cited, the median progression-free survival and objective response rate were better in the gefitinib group (9.2 months vs. 6.3 months and $62.1 \%$ vs. $32.2 \%$, respectively). 
Table 1 - Randomized trials of EGFR-TKls in selected populations rich in activating mutations in the EGFR gene.

\begin{tabular}{|c|c|c|c|c|c|c|c|c|c|c|}
\hline \multirow[t]{3}{*}{ Reference } & \multirow[t]{3}{*}{$\mathrm{N}$} & \multirow{3}{*}{$\begin{array}{c}\text { Prevalence of EGFR } \\
\text { mutations } \\
(\%)\end{array}$} & \multirow[t]{3}{*}{ TK1 } & \multirow{2}{*}{\multicolumn{3}{|c|}{$\begin{array}{c}\text { Response rate }^{*} \\
(\%)\end{array}$}} & \multirow{2}{*}{\multicolumn{4}{|c|}{$\frac{\text { Progression-free survival }^{*}}{\text { (median in months) }^{\text {(median }}}$}} \\
\hline & & & & & & & & & & \\
\hline & & & & TKl & $\mathrm{CT}$ & $p$ & TKI & CT & HR & $\mathrm{p}$ \\
\hline Mok et al. ${ }^{(42)}$ & 1,217 & 60 & $G$ & 71 & 47 & $<0.001$ & 10.0 & 6.0 & 0.48 & $<0.001$ \\
\hline Maemondo et al. ${ }^{(43)}$ & 230 & 100 & G & 74 & 31 & $<0.001$ & 10.8 & 5.4 & 0.36 & $<0.001$ \\
\hline Mitsudomi et al. ${ }^{(44)}$ & 177 & 100 & G & 62 & 32 & $<0.0001$ & 9.2 & 6.3 & 0.49 & $<0.0001$ \\
\hline Zhou et al. ${ }^{(45)}$ & 165 & 100 & E & 83 & 36 & $<0.0001$ & 13.0 & 4.6 & 0.16 & $<0.0001$ \\
\hline Rosell et al. ${ }^{(46)}$ & 174 & 100 & E & 58 & 15 & $<0.0001$ & 9.7 & 5.2 & 0.37 & $<0.0001$ \\
\hline Sequist et al..$^{(47)}$ & 345 & 100 & A & 56 & 23 & 0.001 & 11.1 & 6.9 & 0.58 & 0.001 \\
\hline Wu et al..$^{(48)}$ & 364 & 100 & A & 67 & 23 & $<0.001$ & 11.0 & 5.6 & 0.28 & $<0.0001$ \\
\hline
\end{tabular}

A: afatinib; CT: chemotherapy; E: erlotinib; G: gefitinib; HR: hazard ratio; and TKI: tyrosine-kinase inhibitor. *Among patients with EGFR mutations.

A phase 111 trial comparing the EGFR-TKI erlotinib with the gemcitabine-carboplatin combination showed that the former provided significant gains in progression-free survival (median, 13.1 months vs. 4.6 months) and in the objective response rate ( $83 \%$ vs. $36 \%)^{(45)}$ Another phase 111 trial of erlotinib, designated the EURTAC study, ${ }^{(46)}$ was the first to compare it with platinum-based chemotherapy as a first-line therapy in Caucasian patients with activating mutations in the EGFR gene. The authors of that study also reported that, in comparison with the cytotoxic chemotherapy, treatment with erlotinib provided significant gains in progression-free survival (median, 9.7 months vs. 5.2 months) and in the objective response rate (58\% vs. $15 \%$ ).

In a phase 111 trial designated the LUX-Lung 3 study, ${ }^{(47)}$ afatinib was compared with the current standard of cisplatin plus pemetrexed in the firstline treatment of Asian and non-Asian patients with adenocarcinoma. The authors found that progression-free survival was significantly better in the afatinib group (median, 11.1 months vs. 6.9 months). In that study, the superiority of afatinib over the cisplatin-pemetrexed combination was found to be even greater in patients with common mutations, such as del19 and L858R. It is noteworthy that the LUX-Lung 3 study used the cisplatin-pemetrexed combination, which is considered more effective, as a reference treatment. In a subsequent phase 111 trial, designated the LUX-Lung 6 trial, ${ }^{(48)}$ afatinib was compared with gemcitabine plus cisplatin in Asian patients with tumors harboring EGFR mutations. Median progression-free survival and the response rate were better in the afatinib group than in the gemcitabine-cisplatin group (11 months vs.
5.6 months and $67 \%$ vs. $23 \%$, respectively). ${ }^{(48)}$ Cross-trial comparisons indicate that afatinib provides the longest progression-free survival. A recent combined analysis of the LUX-Lung 3 and LUX-Lung 6 studies (the largest of such trials) suggested an overall survival gain for afatinib over chemotherapy, mainly in patients whose tumors harbor exon 19 deletions. ${ }^{(49)}$

Despite the markedly better activity of first- and second-generation EGFR-TKls, when compared with traditional chemotherapy, no difference in overall survival has been found among mutationrich populations. In the majority of patients with EGFR mutations, second-line treatment with an EGFR-TKl was used in those who had disease progression after chemotherapy, thus obscuring the treatment effect of these agents on overall survival, something that has been demonstrated for the IPASS and EURTAC trials. ${ }^{(46,50)}$ Consequently, when EGFR genotype results are not available, we suggest starting conventional cytotoxic platinum-based chemotherapy in patients with tumor-related symptoms and introducing an EGFR-TK1 only after a mutation has been detected. An EGFR-TK1 could also be used as maintenance therapy, or even as a second-line treatment, given that EGFR-TKls have been shown to have no negative impact on survival. ${ }^{(51)}$

One of the common adverse effects of EGFRTKls is papulopustular (acneiform) rash, which is in fact a favorable prognostic and predictive factor of a response to such drugs. Other reported adverse effects include gastrointestinal symptoms (such as hyperbilirubinemia, diarrhea, nausea, and anorexia), dyspnea, fatigue, and edema, although all of these effects are generally well tolerated and manageable. ${ }^{(52)}$ 
All EGFR-TKls have some penetration across the blood-brain barrier and are therefore effective modes of therapy for patients with central nervous system metastases, as well as being well tolerated by such patients. ${ }^{(53)}$ Treatment with an EGFR-TK1 is particularly helpful when such metastases are small, because it can (in some cases) allow radiation therapy or surgery to be postponed. ${ }^{(53)} \mathrm{A}$ recent phase 11 study confirmed that it is feasible to continue treatment with an EGFR-TK1 (erlotinib) in patients with asymptomatic progressive disease-as determined on the basis of the response evaluation criteria in solid tumors-and showed that such treatment has no impact on overall survival. ${ }^{(54)}$ However, antacids that modify gastric $\mathrm{pH}$ can affect absorption and thus reduce the efficacy of EGFR-TKls. ${ }^{(55)}$

\section{Diagnosing EGFR mutations}

Given the role of activating mutations as predictors of a benefit from EGFR-TKIs, there is a clear need to accurately genotype tumor samples obtained from patients with NSCLC. In some studies, large-scale screening for such mutations has proven feasible. The most widely studied activating mutations (EGFR mutations, Kirsten rat sarcoma viral oncogene homolog mutations, and echinoderm microtubule-associated protein-like 4-anaplastic lymphoma kinase rearrangement) are usually mutually exclusive. Therefore, in day-to-day practice, physicians can discontinue the molecular investigation when one such mutation is identified. It is of note that, because these types of mutations occur in only $5 \%$ of patients with squamous cell carcinoma, such patients are not routinely screened for them. In addition, even if an activating mutation is identified, there is no clear evidence that treatment with EGFR-TKls provides a benefit in cases of squamous cell carcinoma. ${ }^{(56)}$

\section{General recommendations}

At present, there are guidelines recommending screening for EGFR mutations in patients with advanced pulmonary adenocarcinoma who are candidates for first-line therapy with erlotinib, gefitinib, or afatinib, regardless of performance status or smoking history. However, in the adjuvant therapy scenario, it is not recommended to incorporate such screening into the clinical routine, because of the scarcity of data regarding the use of EGFR-TKls in patients with localized or locally advanced disease. ${ }^{(57)}$ It is recommended that greater attention be paid to patients with adenocarcinoma and to those who are never-smokers. Ideally, sample collection for molecular testing should be done at the time of the histological classification of the tumor, the ideal turnaround time being $\leq$ 7 days. It should be borne in mind that mutation screening in blood samples is still considered experimental. ${ }^{(58)}$ Careful consideration should be given to the type of biopsy, taking into account the number of malignant cells likely to be present in the sample, because some mutation-detection techniques require large fractions of tumor cells in the sample. Tissue for molecular testing can be obtained by bronchoscopy, mediastinoscopy, thoracoscopy, pleural biopsy (for malignant pleural effusion), or CT-guided percutaneous biopsy. Endobronchial ultrasound with transbronchial biopsy can also be helpful in select cases. Obtaining bone samples is feasible, although they must be processed only by laboratories with experience, in order to avoid losses. However, other biopsy sites are preferred, if available.

\section{Techniques for identifying EGFR mutations}

\section{Direct DNA sequencing}

First described by Sanger in 1977,(59) direct DNA sequencing has contributed greatly to the development of biotechnology, culminating in the sequencing of a large part of the human genome. The method relies on the so-called dideoxy reaction, in which dideoxynucleotides (ddNTPs) are used in order to interrupt the replication of the genetic material, thus generating segments of different sizes. Fluorescently labeled ddNTPs can reveal the sequence of DNA bases in the sample through the analysis of the various bands thus generated. Although well established and reliable, direct sequencing requires samples containing a large fraction of tumor cells, usually more than $30 \%$ of the sample, a proportion not easily obtained, given that non-neoplastic tissue often comprises most of the biopsy material. Newer sequencing methods show great potential for future application; among them, pyrosequencing deserves mention, because it can detect mutations in samples containing only $0.2 \%$ tumor cells. This extremely sensitive technique can be used in order to detect EGFR mutations in pleural 
effusion samples containing only $10 \%$ of neoplastic cells. However, the method is still not widely available and requires sophisticated, expensive equipment. ${ }^{(60)}$

\section{Methods based on PCR}

The PCR technique can be used not only to amplify genetic material but also to detect mutations of interest. One of the PCR methods most commonly used for the latter purpose is the amplification refractory mutation system (ARMS), which is based on the differential activity of the enzyme Taq DNA polymerase during amplification of sequences that have mismatch points at 3 . The primers used in the ARMS reaction, when pairing with mutated sequences, generate mismatch points, allowing detection of mutations through the identification of differences in the band patterns generated. Kimura et al. ${ }^{(61)}$ reported interesting results from the use of the ARMS technique in samples comprising less than 1\% mutant EGFRcontaining material. According to the College of American Pathologists, laboratories should use EGFR tests that are able to identify mutations in specimens with at least 50\% cancer cells, although it has recently encouraged the use of more sensitive tests that can detect mutations in specimens with less than 10\% cancer cells. ${ }^{(62)}$ The technique known as TaqMan PCR uses probes that are specific for the wild-type and mutant sequences of EGFR. The presence of mutated sequences is indicated by the fluorescence peaks generated. Jian et al. ${ }^{(63)}$ were able to identify mutations in samples comprising at least 10\% mutant EGFR-containing material. ${ }^{(63)}$ This approach facilitates testing by using a single step, no post-PCR processing being required. Variations of the PCR technique include other sensitive methods that apply selective amplification of mutated sequences. Such variations, which display high sensitivity in samples with low proportions of mutant EGFR-containing material, include mutant-enriched PCR assay, peptide nucleic acid-locked nucleic acid PCR clamping, and the smart-amplification process. Using mutant-enriched PCR assay, Asano et al. ${ }^{(64)}$ detected mutations that were present in only $0.05 \%$ of the tumor samples evaluated. These techniques provide new possibilities for developing diagnostic tests that will be capable of detecting mutations in a less invasive manner, often using small samples.

\section{RFLP}

The RFLP technique is based on the use of restriction enzymes, which cleave sequences of genetic material at specific sites. As a result, DNA segments of different sizes are generated according to the presence of mutations. Those segments in turn present different patterns of electrophoretic mobility, which allows the detection of mutations through the analysis of the band patterns observed. Using this method, Pan et al. ${ }^{(65)}$ detected mutations that were present in proportions as low as $6.25 \%$ for exon 19 deletions and 3.25\% for L858R.

\section{Other techniques}

Several other methods for the detection of EGFR mutations have been described. Probes designed specifically for the detection of mutated alleles, such as the cycleave probe, emit a fluorescence peak in the presence of the mutation and have shown good results with samples in which at least 5\% of the cells harbor mutations. ${ }^{(66)}$ Other methods include the so-called loop-hybrid mobility shift assay, the single-strand conformation polymorphism technique, and HPLC. The latter technique, which is a means of comprehensively characterizing the DNA sequence under study and not only previously known mutations, has shown good sensitivity in samples with only $1 \%$ mutated material. ${ }^{(67)}$ Finally, if labeled antibodies are directed against mutant EGFR proteins resulting from the transcription of EGFR genes with known activating mutations, immunohistochemistry can be used to detect mutations of interest. The validation of mutation-specific immunohistochemistry in clinical practice is eagerly awaited, because this technique could greatly facilitate the identification of the patients most likely to benefit from treatment with EGFR-TKls. ${ }^{(68)}$

\section{Final considerations and perspectives}

The latest guidelines for the classification of lung adenocarcinoma recommend including EGFR genotyping in the diagnostic algorithm. ${ }^{(69)}$ The appropriate selection of patients who are potential candidates for EGFR-TK1 therapy becomes even more critical when one considers other genetic alterations observed in lung adenocarcinomas, such 
as RAS mutations, anaplastic lymphoma kinase translocations, and HER-2 amplification. Some of these alterations seem to be mutually exclusive and can also be targeted by specific therapies under development or already in clinical use. ${ }^{(70)}$ Genome-wide projects evaluating multiple genetic changes in patient samples have shown promising results and might lead to the identification of relevant targets for future intervention. ${ }^{(71)}$ Data in the Cancer Genome Atlas suggest that pulmonary adenocarcinoma could be classified by molecular subtype based on next-generation sequencing reads, the new nomenclature for the transcriptional subtypes being terminal respiratory unit (formerly bronchioid), proximal-inflammatory (formerly squamoid), and proximal-proliferative (formerly magnoid). Adenocarcinomas that present activating mutations in the EGFR gene are clustered in the terminal respiratory unit subtype. The other two subtypes (proximal-inflammatory and proximalproliferative) do not seem to be associated with EGFR-mutated tumors. ${ }^{(72)}$

In advanced NSCLC patients with EGFR-wild type tumors, the use of EGFR-TKls cannot be considered a valid second-line treatment option after failure of a platinum-based regimen. ${ }^{(73)}$ In patients with known activating mutations, a TKI can be used as a first-line treatment and should be maintained until there is clinically documented disease progression. ${ }^{(74,75)}$ This "personalized medicine" approach represents a new frontier in modern oncology, in which the treatment of each cancer patient will be targeted according to genetic alterations present in the tumors-treating the right patient with the right drug, at the right dose, and at the right time.

\section{References}

1. Ministério da Saúde. Instituto Nacional do Câncer José Alencar Gomes da Silva [homepage on the Internet]. Rio de Janeiro: INCA [cited 2014 Nov 26]. Estimativa 2014 - Incidência de Câncer no Brasil 2014. [Adobe Acrobat document, 126p.]. Available from: http://www. inca.gov.br/estimativa/2014/estimativa-24012014.pdf

2. Ferlay J, Soerjomataram I, Ervik M, Dikshit R, Eser S, Mathers C, et al. GLOBOCAN 2012 v1.0, Cancer Incidence and Mortality Worldwide: IARC CancerBase No. 11 [monograph on the Internet]. Lyon, France: International Agency for Research on Cancer; 2013 [cited 2015 Mar 23]. Available from: http://globocan.iarc.fr

3. Guimarães RM, Santos TS. Mortality distribution due to tracheal, lung, and bronchial cancer by gender, Brazil, 1980-2010. J Bras Pneumol. 2013;39(5):633-5. http:// dx.doi.org/10.1590/S1806-37132013000500016
4. Schiller JH, Harrington D, Belani CP, Langer C, Sandler A, Krook J, et al. Comparison of four chemotherapy regimens for advanced non-small-cell lung cancer. $\mathrm{N}$ Engl J Med. 2002;346(2):92-8. http://dx.doi.org/10.1056/ NEJMoa011954

5. Paez JG, Jänne PA, Lee JC, Tracy S, Greulich H, Gabriel $S$, et al. EGFR mutations in lung cancer: correlation with clinical response to gefitinib therapy. Science. 2004;304(5676):1497-500. http://dx.doi.org/10.1126/ science. 1099314

6. Lynch TJ, Bell DW, Sordella R, Gurubhagavatula S, Okimoto RA, Brannigan BW, et al. Activating mutations in the epidermal growth factor receptor underlying responsiveness of non-small-cell lung cancer to gefitinib. N Engl J Med. 2004;350(21):2129-39. http://dx.doi. org/10.1056/NEJMoa040938

7. Cohen S. The stimulation of epidermal proliferation by a specific protein (EGF). Dev Biol. 1965;12(3):394-407. http://dx.doi.org/10.1016/0012-1606(65)90005-9

8. Mendelsohn J, Baselga J. The EGF receptor family as targets for cancer therapy. Oncogene. 2000;19(56):655065. http://dx.doi.org/10.1038/sj.onc. 1204082

9. Lemmon MA, Bu Z, Ladbury JE, Zhou M, Pinchasi D, Lax l, et al. Two EGF molecules contribute additively to stabilization of the EGFR dimer. EMBO J. 1997;16(2):28194. http://dx.doi.org/10.1093/emboj/16.2.281

10. Downward J, Parker P, Waterfield MD. Autophosphorylation sites on the epidermal growth factor receptor. Nature. 1984;311(5985):483-5. http://dx.doi.org/10.1038/311483a0

11. van der Geer P, Pawson T. The PTB domain: a new protein module implicated in signal transduction. Trends Biochem Sci. 1995;20(7):277-80. http://dx.doi.org/10.1016/ S0968-0004(00)89043-X

12. Seger R, Krebs EG. The MAPK signaling cascade. FASEB J. 1995;9(9):726-35.

13. Buday L, Downward J. Epidermal growth factor regulates p21ras through the formation of a complex of receptor, Grb2 adapter protein, and Sos nucleotide exchange factor. Cell. 1993;73(3):611-20. http://dx.doi. org/10.1016/0092-8674(93)90146-H

14. Fresno Vara JA, Casado E, de Castro J, Cejas P, BeldaIniesta C, González-Barón M. PI3K/Akt signalling pathway and cancer. Cancer Treat Rev. 2004;30(2):193-204. http://dx.doi.org/10.1016/j.ctrv.2003.07.007

15. Downward J, Yarden Y, Mayes E, Scrace G, Totty $\mathrm{N}$, Stockwell P, et al. Close similarity of epidermal growth factor receptor and v-erb-B oncogene protein sequences. Nature. 1984;307(5951):521-7. http://dx.doi. org/10.1038/307521a0

16. Yarden $\mathrm{Y}$, Sliwkowski MX. Untangling the ErbB signalling network. Nat Rev Mol Cell Biol. 2001;2(2):127-37. http:// dx.doi.org/10.1038/35052073

17. Cohen MH, Williams GA, Sridhara R, Chen G, McGuinn WD Jr, Morse D, et al. United States Food and Drug Administration Drug Approval summary: Gefitinib (ZD1839; Iressa) tablets. Clin Cancer Res. 2004;10(4):1212-8. http://dx.doi.org/10.1158/1078-0432.CCR-03-0564

18. Cohen MH, Johnson JR, Chen YF, Sridhara R, Pazdur R. FDA drug approval summary: erlotinib (Tarceva) tablets. Oncologist. 2005;10(7):461-6. http://dx.doi.org/10.1634/ theoncologist.10-7-461

19. Dungo RT, Keating GM. Afatinib: first global approval. Drugs. 2013;73(13):1503-15. http://dx.doi.org/10.1007/ s40265-013-0111-6 
20. Baselga J, Albanell J. Epithelial growth factor receptor interacting agents. Hematol Oncol Clin North Am. 2002;16(5):1041-63. http://dx.doi.org/10.1016/ S0889-8588(02)00055-2

21. Bianco C, Tortora G, Bianco R, Caputo R, Veneziani BM, Caputo R, et al. Enhancement of antitumor activity of ionizing radiation by combined treatment with the selective epidermal growth factor receptor-tyrosine kinase inhibitor ZD1839 (Iressa). Clin Cancer Res. 2002;8(10):3250-8.

22. Fukuoka M, Yano S, Giaccone G, Tamura T, Nakagawa K, Douillard JY, et al. Multi-institutional randomized phase 11 trial of gefitinib for previously treated patients with advanced non-small-cell lung cancer (The IDEAL 1 Trial) [corrected]. J Clin Oncol. 2003;21(12):223746. Erratum in: J Clin Oncol. 2004 Dec 1;22(23):4863. http://dx.doi.org/10.1200/JC0.2003.10.038

23. Kris MG, Natale RB, Herbst RS, Lynch TJ Jr, Prager D, Belani CP, et al. Efficacy of gefitinib, an inhibitor of the epidermal growth factor receptor tyrosine kinase, in symptomatic patients with non-small cell lung cancer: a randomized trial. JAMA. 2003;290(16):2149-58. http:// dx.doi.org/10.1001/jama.290.16.2149

24. Giaccone G, Herbst RS, Manegold C, Scagliotti G, Rosell R, Miller V, et al. Gefitinib in combination with gemcitabine and cisplatin in advanced non-small-cell lung cancer: a phase III trial--INTACT 1. J Clin Oncol. 2004;22(5):77784. http://dx.doi.org/10.1200/JC0.2004.08.001

25. Herbst RS, Giaccone G, Schiller JH, Natale RB, Miller $\mathrm{V}$, Manegold C, et al. Gefitinib in combination with paclitaxel and carboplatin in advanced non-smallcell lung cancer: a phase 111 trial--INTACT 2. J Clin Oncol. 2004;22(5):785-94. http://dx.doi.org/10.1200/ JC0.2004.07.215

26. Herbst RS, Prager D, Hermann R, Fehrenbacher L, Johnson BE, Sandler A, et al. TRIBUTE: a phase 111 trial of erlotinib hydrochloride (OSI-774) combined with carboplatin and paclitaxel chemotherapy in advanced non-small-cell lung cancer. J Clin Oncol. 2005;23(25):5892-9. http:// dx.doi.org/10.1200/JC0.2005.02.840

27. Gatzemeier U, Pluzanska A, Szczesna A, Kaukel E, Roubec J, De Rosa F, et al. Phase Ill study of erlotinib in combination with cisplatin and gemcitabine in advanced non-small-cell lung cancer: the Tarceva Lung Cancer Investigation Trial. J Clin Oncol. 2007;25(12):1545-52. http://dx.doi.org/10.1200/JC0.2005.05.1474

28. Shepherd FA, Rodrigues Pereira J, Ciuleanu T, Tan EH, Hirsh V, Thongprasert S, et al. Erlotinib in previously treated non-small-cell lung cancer. $\mathrm{N}$ Engl J Med. 2005;353(2):123-32. http://dx.doi.org/10.1056/ NEJMoa050753

29. Jänne PA, Gurubhagavatula S, Yeap BY, Lucca J, Ostler P, Skarin AT, et al. Outcomes of patients with advanced non-small cell lung cancer treated with gefitinib (ZD1839, "Iressa") on an expanded access study. Lung Cancer. 2004;44(2):221-30. http://dx.doi.org/10.1016/j. lungcan.2003.12.014

30. Thatcher N, Chang A, Parikh P, Rodrigues Pereira J, Ciuleanu T, von Pawel J, et al. Gefitinib plus best supportive care in previously treated patients with refractory advanced non-small-cell lung cancer: results from a randomised, placebo-controlled, multicentre study (Iressa Survival Evaluation in Lung Cancer). Lancet. 2005;366(9496):152737. http://dx.doi.org/10.1016/S0140-6736(05)67625-8

31. Kim ES, Hirsh V, Mok T, Socinski MA, Gervais R, Wu YL, et al. Gefitinib versus docetaxel in previously treated non-small-cell lung cancer (INTEREST): a randomised phase 111 trial. Lancet. 2008;372(9652):1809-18. http:// dx.doi.org/10.1016/S0140-6736(08)61758-4

32. Hanna N, Shepherd FA, Fossella FV, Pereira JR, De Marinis F, von Pawel J, et al. Randomized phase 111 trial of pemetrexed versus docetaxel in patients with non-small-cell lung cancer previously treated with chemotherapy. J Clin Oncol. 2004;22(9):1589-97. http://dx.doi.org/10.1200/ JC0.2004.08.163

33. Fukui T, Mitsudomi T. Mutations in the epidermal growth factor receptor gene and effects of EGFR-tyrosine kinase inhibitors on lung cancers. Gen Thorac Cardiovasc Surg. 2008;56(3):97-103. http://dx.doi.org/10.1007/ s11748-007-0193-8

34. Greulich H, Chen TH, Feng W, Jänne PA, Alvarez JV, Zappaterra M, et al. Oncogenic transformation by inhibitor-sensitive and -resistant EGFR mutants. PLoS Med. 2005;2(11):e313. http://dx.doi.org/10.1371/journal. pmed.0020313

35. Okabe T, Okamoto I, Tamura K, Terashima M, Yoshida $\mathrm{T}$, Satoh T, et al. Differential constitutive activation of the epidermal growth factor receptor in non-small cell lung cancer cells bearing EGFR gene mutation and amplification. Cancer Res. 2007;67(5):2046-53. http:// dx.doi.org/10.1158/0008-5472.CAN-06-3339

36. Akca H, Tani M, Hishida T, Matsumoto S, Yokota J. Activation of the AKT and STAT3 pathways and prolonged survival by a mutant EGFR in human lung cancer cells. Lung Cancer. 2006;54(1):25-33. http://dx.doi.org/10.1016/j. lungcan.2006.06.007

37. Pontes LdeB, Bacchi CE, Queiroga EM, Piha T, Miranda PA, Freire $S$, et al. EGFR mutation screening in non-small cell lung cancer: results from an access program in Brazil. J Clin Oncol. 2014;32:5s (suppl; abstr 1526).

38. Bacchi CE, Ciol H, Queiroga EM, Benine LC, Silva LH, Ojopi $\mathrm{EB}$, et al. Epidermal growth factor receptor and KRAS mutations in Brazilian lung cancer patients. Clinics (Sao Paulo). 2012;67(5): 419-24. http://dx.doi.org/10.6061/ clinics/2012(05)03

39. Li D, Ambrogio L, Shimamura T, Kubo S, Takahashi M, Chirieac LR, et al. BIBW2992, an irreversible EGFR/ HER2 inhibitor highly effective in preclinical lung cancer models. Oncogene. 2008;27(34):4702-11. http://dx.doi. org/10.1038/onc.2008.109

40. Spigel DR, Ervin TJ, Ramlau R, Daniel DB, Goldschmidt $\mathrm{JH}$, Blumenschein GR, et al. Final efficacy results from OAM4558g, a randomized phase 11 study evaluating MetMAb or placebo in combination with erlotinib in advanced NSCLC. J Clin Oncol. 2011;29 (suppl; abstr 7505).

41. Scagliotti GV, Novello S, Schiller JH, Hirsh V, Sequist LV, Soria JC, et al. Rationale and design of MARQUEE: a phase 11l, randomized, double-blind study of tivantinib plus erlotinib versus placebo plus erlotinib in previously treated patients with locally advanced or metastatic, nonsquamous, non-small-cell lung cancer. Clin Lung Cancer. 2012;13(5):391-5. http://dx.doi.org/10.1016/j. cllc.2012.01.003

42. Mok TS, Wu YL, Thongprasert S, Yang CH, Chu DT, Saijo $\mathrm{N}$ et al. Gefitinib or carboplatin-paclitaxel in pulmonary adenocarcinoma. N Engl J Med. 2009;361(10):947-57. http://dx.doi.org/10.1056/NEJMoa0810699

43. Maemondo M, Inoue A, Kobayashi K, Sugawara S, Oizumi S, lsobe H, et al. Gefitinib or chemotherapy for non-small-cell lung cancer with mutated EGFR. N Engl 
J Med. 2010;362(25):2380-8. http://dx.doi.org/10.1056/ NEJMoa0909530

44. Mitsudomi T, Morita S, Yatabe Y, Negoro S, Okamoto 1, Tsurutani J, et al. Gefitinib versus cisplatin plus docetaxel in patients with non-small-cell lung cancer harbouring mutations of the epidermal growth factor receptor (WJTOG3405): an open label, randomised phase 3 trial. Lancet Oncol. 2010;11(2):121-8. http://dx.doi. org/10.1016/S1470-2045(09)70364-X

45. Zhou C, Wu YL, Chen G, Feng J, Liu XQ, Wang C, et al. Erlotinib versus chemotherapy as first-line treatment for patients with advanced EGFR mutation-positive non-small-cell lung cancer (OPTIMAL, CTONG-0802): a multicentre, open-label, randomised, phase 3 study. Lancet Oncol. 2011;12(8):735-42. http://dx.doi.org/10.1016/ S1470-2045(11)70184-X

46. Rosell R, Carcereny E, Gervais R, Vergnenegre A, Massuti B, Felip E, et al. Erlotinib versus standard chemotherapy as first-line treatment for European patients with advanced EGFR mutation-positive non-small-cell lung cancer (EURTAC): a multicentre, open-label, randomised phase 3 trial. Lancet Oncol. 2012;13(3):239-46. http://dx.doi. org/10.1016/S1470-2045(11)70393-X

47. Sequist LV, Yang JC, Yamamoto N, O’Byrne K, Hirsh $\mathrm{V}$, Mok T, et al. Phase 111 study of afatinib or cisplatin plus pemetrexed in patients with metastatic lung adenocarcinoma with EGFR mutations. J Clin Oncol. 2013;31(27):3327-34. http://dx.doi.org/10.1200/ JC0.2012.44.2806

48. Wu YL, Zhou C, Hu CP, Feng J, Lu S, Huang Y, et al. Afatinib versus cisplatin plus gemcitabine for first-line treatment of Asian patients with advanced non-smallcell lung cancer harbouring EGFR mutations (LUX-Lung 6): an open-label, randomised phase 3 trial. Lancet Oncol. 2014;15(2):213-22. http://dx.doi.org/10.1016/ S1470-2045(13)70604-1

49. Yang JC, Wu YL, Schuler M, Sebastian M, Popat S, Yamamoto N, et al. Afatinib versus cisplatin-based chemotherapy for EGFR mutation-positive lung adenocarcinoma (LUX-Lung 3 and LUX-Lung 6): analysis of overall survival data from two randomised, phase 3 trials. Lancet Oncol. 2015;16(2):141-51. http://dx.doi. org/10.1016/S1470-2045(14)71173-8

50. Fukuoka M, Wu YL, Thongprasert S, Sunpaweravong P, Leong SS, Sriuranpong V, et al. Biomarker analyses and final overall survival results from a phase 111 , randomized, open-label, first-line study of gefitinib versus carboplatin/ paclitaxel in clinically selected patients with advanced non-small-cell lung cancer in Asia (IPASS). J Clin Oncol. 2011;29(21):2866-74. http://dx.doi.org/10.1200/ JC0.2010.33.4235

51. Rosell R, Moran T, Queralt C, Porta R, Cardenal F, Camps $C$, et al. Screening for epidermal growth factor receptor mutations in lung cancer. N Engl J Med. 2009;361(10):95867. http://dx.doi.org/10.1056/NEJMoa0904554

52. Lacouture ME, Anadkat MJ, Bensadoun RJ, Bryce J, Chan A, Epstein JB, et al. Clinical practice guidelines for the prevention and treatment of EGFR inhibitorassociated dermatologic toxicities. Support Care Cancer. 2011;19(8):1079-95. http://dx.doi.org/10.1007/ s00520-011-1197-6

53. Berger LA, Riesenberg H, Bokemeyer C, Atanackovic D. CNS metastases in non-small-cell lung cancer: current role of EGFR-TKI therapy and future perspectives. Lung
Cancer. 2013;80(3):242-8. http://dx.doi.org/10.1016/j. lungcan.2013.02.004

54. Park K, Ahn M, Yu C, Kim S, Lin M, Sriuranpong V, et al. ASPIRATION: first-line erlotinib (E) until and beyond RECIST progression (PD) in Asian patients (pts) with EGFR mutation-positive (mut+) NSCLC. Ann Oncol. 2014;25 (suppl 4):iv426-iv427. http://dx.doi.org/10.1093/ annonc/mdu349.2

55. Cataldo VD, Gibbons DL, Pérez-Soler R, Quintás-Cardama A. Treatment of non-small-cell lung cancer with erlotinib or gefitinib. N Engl J Med. 2011;364(10):947-55. http:// dx.doi.org/10.1056/NEJMct0807960

56. Barlesi F, Blons H, Beau-Faller M, Rouquette 1, Ouafik L, Mosser J, et al. Biomarkers (BM) France: Results of routine EGFR, HER2, KRAS, BRAF, PI3KCA mutations detection and EML4-ALK gene fusion assessment on the first 10,000 non-small cell lung cancer (NSCLC) patients (pts). J Clin Oncol. 2013;31 (suppl; abstr 8000).

57. Lindeman NI, Cagle PT, Beasley MB, Chitale DA, Dacic $\mathrm{S}$, Giaccone $\mathrm{G}$, et al. Molecular testing guideline for selection of lung cancer patients for EGFR and ALK tyrosine kinase inhibitors: guideline from the College of American Pathologists, International Association for the Study of Lung Cancer, and Association for Molecular Pathology. J Thorac Oncol. 2013;8(7):823-59. http:// dx.doi.org/10.1097/JT0.0b013e318290868f

58. Maheswaran S, Sequist LV, Nagrath S, Ulkus L, Brannigan B, Collura CV, et al. Detection of mutations in EGFR in circulating lung-cancer cells. $\mathrm{N}$ Engl J Med. 2008;359(4):366-77. http://dx.doi.org/10.1056/ NEJMoa0800668

59. Sanger F, Nicklen S, Coulson AR. DNA sequencing with chain-terminating inhibitors. Proc Natl Acad Sci U S A. 1977;74(12):5463-7. http://dx.doi.org/10.1073/ pnas.74.12.5463

60. Pao W, Ladanyi M. Epidermal growth factor receptor mutation testing in lung cancer: searching for the ideal method. Clin Cancer Res. 2007;13(17):4954-5. http:// dx.doi.org/10.1158/1078-0432.CCR-07-1387

61. Kimura H, Kasahara K, Kawaishi M, Kunitoh H, Tamura T, Holloway B, et al. Detection of epidermal growth factor receptor mutations in serum as a predictor of the response to gefitinib in patients with non-small-cell lung cancer. Clin Cancer Res. 2006;12(13):3915-21. http://dx.doi.org/10.1158/1078-0432.CCR-05-2324

62. Leighl NB, Rekhtman N, Biermann WA, Huang J, MinoKenudson M, Ramalingam SS, et al. Molecular testing for selection of patients with lung cancer for Epidermal Growth Factor Receptor and Anaplastic Lymphoma Kinase tyrosine kinase inhibitors: American Society of Clinical Oncology endorsement of the College of American Pathologists/International Association for the Study of Lung Cancer/Association for Molecular Pathology guideline. J Clin Oncol. 2014;32(32):3673-9. http:// dx.doi.org/10.1200/JC0.2014.57.3055

63. Jian G, Songwen Z, Ling Z, Qinfang D, Jie Z, Liang T, et al. Prediction of epidermal growth factor receptor mutations in the plasma/pleural effusion to efficacy of gefitinib treatment in advanced non-small cell lung cancer. J Cancer Res Clin Oncol. 2010;136(9):1341-7. http://dx.doi.org/10.1007/s00432-010-0785-z

64. Asano H, Toyooka S, Tokumo M, Ichimura K, Aoe K, Ito $S$, et al. Detection of EGFR gene mutation in lung cancer by mutant-enriched polymerase chain reaction 
assay. Clin Cancer Res. 2006;12(1):43-8. http://dx.doi. org/10.1158/1078-0432.CCR-05-0934

65. Pan Q, Pao W, Ladanyi M. Rapid polymerase chain reaction-based detection of epidermal growth factor receptor gene mutations in lung adenocarcinomas. $\mathrm{J}$ Mol Diagn. 2005;7(3):396-403. http://dx.doi.org/10.1016/ S1525-1578(10)60569-7

66. Yatabe Y, Hida T, Horio Y, Kosaka T, Takahashi T, Mitsudomi T. A rapid, sensitive assay to detect EGFR mutation in small biopsy specimens from lung cancer. J Mol Diagn. 2006;8(3):335-41. http://dx.doi.org/10.2353/ jmoldx.2006.050104

67. Chin TM, Anuar D, Soo R, Salto-Tellez M, Li WQ, Ahmad B, et al. Detection of epidermal growth factor receptor variations by partially denaturing HPLC. Clin Chem. 2007;53(1):62-70. http://dx.doi.org/10.1373/ clinchem.2006.074831

68. Simonetti S, Molina MA, Queralt C, de Aguirre 1, Mayo C, Bertran-Alamillo J, et al. Detection of EGFR mutations with mutation-specific antibodies in stage IV non-smallcell lung cancer. J Transl Med. 2010;8:135. http://dx.doi. org/10.1186/1479-5876-8-135

69. Travis WD, Brambilla E, Noguchi M, Nicholson AG, Geisinger KR, Yatabe $\mathrm{Y}$, et al. International Association for the Study of Lung Cancer/American Thoracic Society/ European Respiratory Society international multidisciplinary classification of lung adenocarcinoma. J Thorac Oncol. 2011;6(2):244-85. http://dx.doi.org/10.1097/ JT0.0b013e318206a221
70. Shaw AT, Kim DW, Nakagawa K, Seto T, Crinó L, Ahn MJ, et al. Crizotinib versus chemotherapy in advanced ALK-positive lung cancer. N Engl J Med. 2013;368(25):2385-94. http://dx.doi.org/10.1056/NEJMoa 1214886

71. Weir BA, Woo MS, Getz G, Perner S, Ding L, Beroukhim $\mathrm{R}$, et al. Characterizing the cancer genome in lung adenocarcinoma. Nature. 2007;450(7171):893-8. http:// dx.doi.org/10.1038/nature06358

72. Cancer Genome Atlas Research Network. Comprehensive molecular profiling of lung adenocarcinoma. Nature. 2014;511(7511):543-50. Erratum in: Nature. 2014;514(7521):262. http://dx.doi.org/10.1038/nature13385

73. Garassino MC, Martelli O, Broggini M, Farina G, Veronese $\mathrm{S}$, Rulli E, et al. Erlotinib versus docetaxel as second-line treatment of patients with advanced non-small-cell lung cancer and wild-type EGFR tumours (TAILOR): a randomised controlled trial. Lancet Oncol. 2013;14(10):981-8. http:// dx.doi.org/10.1016/S1470-2045(13)70310-3

74. Jackman D, Pao W, Riely GJ, Engelman JA, Kris MG, Jänne PA, et al. Clinical definition of acquired resistance to epidermal growth factor receptor tyrosine kinase inhibitors in non-small-cell lung cancer. J Clin Oncol. 2010;28(2):357-60. http://dx.doi.org/10.1200/ JC0.2009.24.7049

75. Cappuzzo F, Ciuleanu T, Stelmakh L, Cicenas S, Szczésna A, Juhász E, et al. Erlotinib as maintenance treatment in advanced non-small-cell lung cancer: a multicentre, randomised, placebo-controlled phase 3 study. Lancet Oncol. 2010;11(6):521-9. http://dx.doi.org/10.1016/ S1470-2045(10)70112-1 